\title{
Strengthening The Nation Character for Students in Border Area
}

\author{
Aunurrahman \\ Universitas Tanjungpura, Pontianak, Indonesia \\ E-mail: aunuruntan@gmail.com
}

\begin{abstract}
This study aims to obtain information about strengthening national character for students in the border area, with a focus on the assessment of strengthening programs, program specificities, the actualization of program implementation, and monitoring patterns, monitoring, evaluation and follow-up of character strengthening programs for students in the border area. The study was conducted by combining quantitative and qualitative approaches through data deepening of students in two Senior High Schools (SMA) in border areas, namely SMA Negeri I and SMA Negeri II Balai Karangan, Sanggau district. Through questionnaires, in-depth interviews and Focus Group Discussions (FGD) it was concluded that the general character strengthening program had been carried out quite well, which was marked by a character strengthening program, schools had good initiatives in developing student character strengthening programs, education character has been carried out through the learning process and outside the learning process. Observation, monitoring, evaluation, and follow-up can already be implemented in character strengthening programs for students in the border area. The main supporting factor in the implementation of character strengthening is that there has been a good synergy between schools, parents and the community in character strengthening program in the border areas. Dimensions that have not been optimal are the absence of specific programs that characterize character reinforcement for students in the border area, program socialization has not been carried out thoroughly and the involvement of parents in the discussion of the results of monitoring and evaluation that is not optimal.
\end{abstract}

Keywords: Strengthening Character Education, Border Areas

\section{INTRODUCTION}

Efforts to direct the behavior of every citizen by the norms of life in society and nation, demand commitment and sincerity of all parties. This is mainly due to the strong character and mentality of the community that is not formed naturally, but through dynamic social interaction and a series of targeted and sustainable development programs. The process of social interaction can have a positive or negative impact on individuals and society. To minimize the negative impact, defense forces are needed on the individual, and are also supported by programs and planned efforts that are intentionally designed to strengthen the resilience of the individual or the community so that they have a strong character, especially in the face of various negative influences. That is why, with the education of human character as individuals and as a society, it can be directed according to the ideal demands for the processes needed by educational institutions and development of a nation because through character education, positive habits that support development develop and develop. The results of research conducted by Maunah (2015: 94), found that character education can prove to have an impact on students in terms of; (a) high motivation to be honest all the time, (b) not lie with anyone, (c) always respect the older and love each other, (d) be grateful for what has been received, (e) worship together, ( f) appreciate the work of others, (g) be trained to be a strong future leader, (h) be trained to do tasks creatively, (i) accustomed to thinking to be independent, (j) trained to care for the environment, $(\mathrm{k})$ trained to help friends in need help.

An expert character, Jakoep Ezra suggested that character is the result of formation, not created but must go through a process. There really is a basic character that contains strength and us. To develop character,needed character education is. We cannot grow alone in good character (Soedarsono, 2009). A coach is needed, who directs and informs the mistakes and weaknesses of our character. Communities with a majority of negative characters are not able to build civilization, let alone become a society that has a high civilization and is of great benefit to humanity (Azis, 2009: 23). Nations that have faded their original character / character lost their identity will continue to be in a downturn (Amin. 2013: 11)

The formation of individual characters has a very important position, because in addition to the personal 
interests concerned, individual characters will also give a large contribution to the formation of a dignified national character and a supporting factor for the process of accelerating the development of a nation. In school education institutions, through education, students who come from various groups of differences are then guided to know each other's ways of life, customs, understand their aspirations, and to recognize and respect that each population group is guided to recognize and respect the rights and to declare themselves according to their respective ways in the corridors of values adopted (Aunurrahman, 2010: 46. Through various planned programs, as well as through the civilizing process, it is believed that individual characters will be formed, moreover if these efforts are carried out early. and Jacobus (2015), argues that character education is related to the effort or process of changing the nature, psychology, character, character of a person or group of people to become a full adult / human being, human beings.

Based on observations of everyday phenomena in today's children's environment the stronger the tendency they are away from li environment and cultural values. As a result of technological advances and changes in the orientation and perspective of parents, children are even more alien and less familiar with the cultural values of the environmental community. In their daily lives they are even closer to technological devices, both packaged in game forms and in the form of entertainment media. Ironically, whether we realize it or not, many parents also support the development of such conditions. Some parents actually give wide opportunities to watch information or performances that are global in nuances. Of course this isn't all bad. It will be more important and wise if the insight and technology and global orientation do not deny the orientation of values that are able to develop positive character of children.

In every educational institution, the effort to find and develop a strengthening approach to character education that is in accordance with the background of the community or the values developed in the environment of students needs to be explored. Strengthening the right character education is very necessary, because even though the educational goals to be achieved are something that is right and good, but if it is done inappropriately, it is very possible that the character dimensions to be developed cannot be realized as expected. The results of research conducted by Roso (2013) show that through character education that emphasizes religious values, traditions and school culture is proven to reinforce students' character development in an integrative manner. That is why in the era of regional autonomy and various regulations on education, educators are given more open space to be creative in seeking character formation in a holistic and integral manner (Majid (2010: 58)

.Starting from the background analysis above, this research is substantially directed to finding information about strengthening the national character in the perspective of teachers in the border area, this departs from an awareness of the importance of the role of schools and the environment in which the school is in supporting the strengthening of character education, as the results of research conducted by
Revell \& Arthur (2007) reveal that of the 1,000 teachers in the two universities said that they are very supportive of the character or moral development efforts they get from the university, but not all of them can develop the character and morals, because it will depend on the conditions and climate of the school they are in your work.

Objective information about strengthening character in border areas, especially for students, is of course very important. Through the description and discussion of Partnership Policy Paper No. 2/2011, it was stated that in some areas far from Indonesian government offices, people on the border actually got a lot of administrative facilities and public services from neighboring countries to split their nationalism. Access to communication and information is also often more easily obtained from neighboring countries that have developed their border areas.

Informal juridical terms, in Law Number 25 of 2000 concerning the National Development Program (PROPERNAS), it is explained that the priority program for the development of border areas aims to improve living standards, welfare of the people, and strengthen order and security of regions bordering other countries. the border needs special attention and is a top priority. This priority program is outlined in the Annual Development Plan (REPETA) which is prepared annually and aims to maintain the territorial integrity of the Unitary Republic of Indonesia (NKRI) and make the border region the front porch of the country through delimitation and demarcation of borders, safeguarding border areas and socio-economic development region along the border.

Through this research it is expected to obtain specific and objective information about strengthening national character for students in the border area, with data deepening at SMA Negeri I and SMA Negeri II Balai Karangan, Sanggau Regency, focusing on character strengthening programs, specificities of priority programs or programs strengthening the nation's character for students designed by schools, actualizing program implementation, supervision, monitoring, evaluation and follow-up of character strengthening programs for students in the border area.

\section{RESEARCH METHOD}

In accordance with the essence of the problems being studied and the research objectives formulated, the research was conducted by combining quantitative and qualitative approaches. The quantitative approach is mainly used to assess the teacher's perception of a program to strengthen character education for students in border areas based on the aspects that have been formulated. While the qualitative approach is more directed to review information / data specifically and deeply according to perspective, Principal, teacher and parents of students. The research subjects were the Principal and the teachers and parents of the students at SMA Negeri I and SMA Negeri II Balai Karangan, which are two State Secondary Schools located in Balai Karangan, Sanggau district, which is directly limited to neighboring Serawak Malaysia. Data was collected through 
questionnaires, focus group discussions and interviews with principals, teachers and parents. Quantitative data obtained through questionnaires were analyzed quantitatively to examine the teacher's answers to the aspects studied and then displayed in graphical form. That the data obtained through focus group discussions and interviews are qualitatively analyzed and subsequently displayed narratively.

\section{RESULT AND DISCUSSION}

Data regarding the dimensions studied in this study are categorized based on quantitative and qualitative data. Quantitative data is presented in the form of graphs and qualitative data is presented narratively. The following is presented quantitative data in the form of graphs that illustrate information / activities from 4 aspects of strengthening student character that are studied, namely character strengthening programs, specificities of programs or priority programs for strengthening national character for students designed by schools, actualization of program implementation, supervision, monitoring, evaluation and follow-up of character strengthening programs for students in the border area.

\section{Strengthening Characteristics of Students in Border Areas} The

results of data analysis regarding the character strengthening program for students in the border area are as shown in the following.

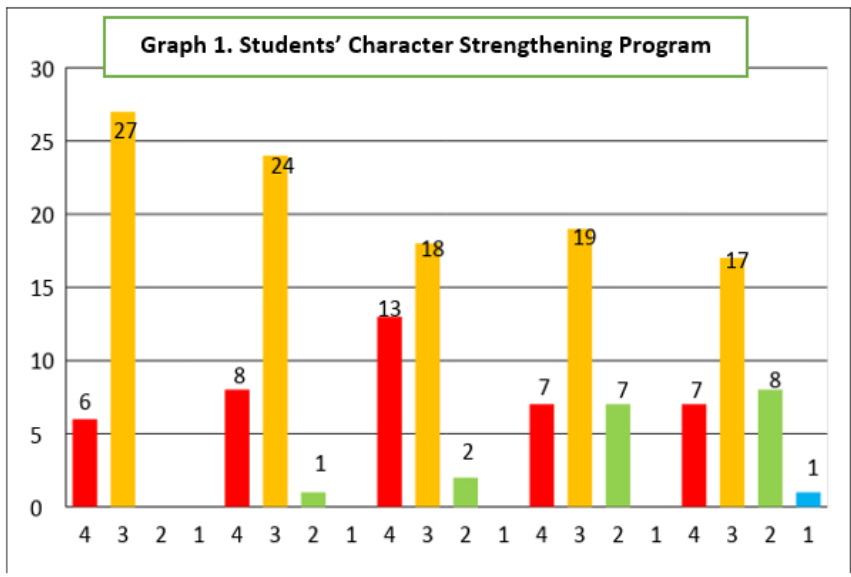

The data in the graph above shows that the application of ethics, the data in the graph above shows that the program of strengthening student character education is available where the instruction and socialization involve teachers in the school. From several more specific dimensions can be explained as follows:

a. The school has a sufficient character strengthening program. This is supported by data showing that most teachers $(81.81 \%)$ said that schools have character strengthening programs that are known to all teachers.

b. The school already has good initiatives in developing student character strengthening programs. This statement is supported by data showing as much as $72.72 \%$, saying that the student character strengthening program was prepared and developed by schools (not only implementing programs prepared by the Office of Education and Culture and the government).

c. The scope of the student character strengthening program is still not too comprehensive. This statement is based on data showing that $54.54 \%$ of teachers said that the program to strengthen the character of students included comprehensive aspects (which included curricular, curricular and extracurricular activities)

d. The involvement of teachers in developing student character strengthening programs is quite good. Although there are quite a large number of teachers who say that not all teachers are involved. This statement is supported by data showing as much as $57.57 \%$, saying that all teachers are involved in the preparation of student character strengthening programs.

e. The socialization of the program to strengthen character education for students has not been carried out thoroughly. This can be seen from the data on the graph which shows $51.51 \%$ of teachers said that the character strengthening program was well socialized to teachers, students, and parents. In addition, it says less and is not socialized.

2. Specialization of Character Strengthening Program for Students in Border Areas.

The results of data analysis regarding the specificity of the program to strengthen character education for students in the border area are as illustrated in the following graph.

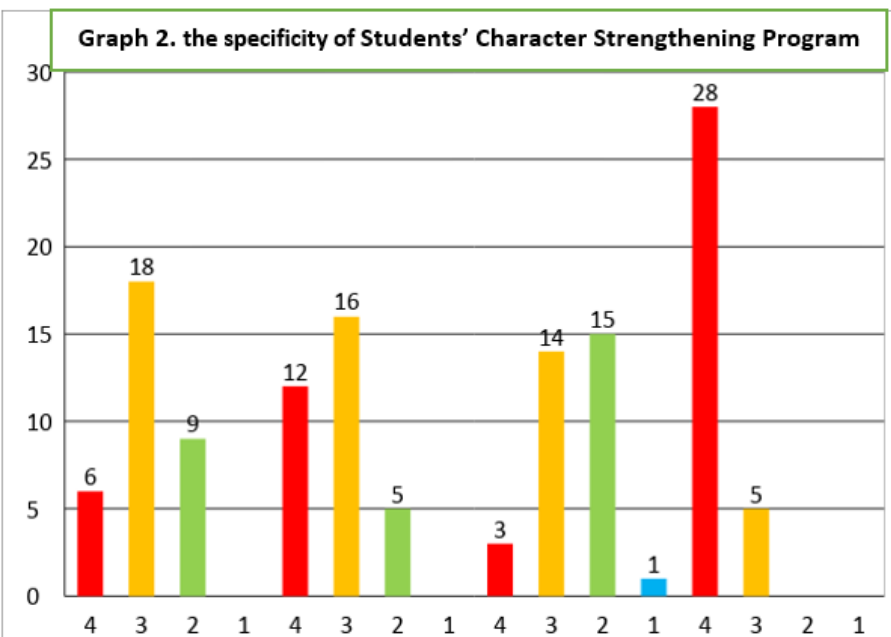

The data in the graph above shows that the specificity of the program of strengthening the character of students in the border area is generally not too visible, although there are certain emphases during implementation. In the meantime, almost all teachers have a perception that schools in border areas should have special programs in strengthening student character. The following are specified dimensions based on the graphical presentation above. 
a. Emphasis on certain characters in the student character strengthening program has not been optimal. Data on graphical presentation shows that $54.54 \%$ of teachers said that as a school with a border area, the character education program developed at the school has special characteristics.

b. Efforts to recognize and explore the condition of the border area to find special characters developed in the student character strengthening program have not been carried out properly. Data on graphical presentation shows that $48.48 \%$ of teachers said that it was quite appropriate. In that there were $36.36 \%$ of the teachers said it was very appropriate.

c. The involvement of parents in the discussion related to character education programs is still not optimal. This is supported by data as much as $45.45 \%$ who say less, and as much as $42.42 \%$ even said that they never involved parents at all in discussing specifically the condition of the border area was associated with strengthening the character of students.

d. Teachers' perceptions of the importance of strengthening special characters, for students in the border area show a very high percentage. Based on the data presented, the majority of teachers $(84.84 \%)$ thought it was very important that schools develop certain characters or special characters in schools in the border area.

3. Implementation of Student Character Strengthening Programs in Schools in Border Regions The

results of data analysis regarding the implementation of student character strengthening programs in schools in the border areas are generally good enough, although some dimensions still need optimization efforts to achieve expected.

The following is illustrated the data about the implementation of student character strengthening programs as in the following graph.

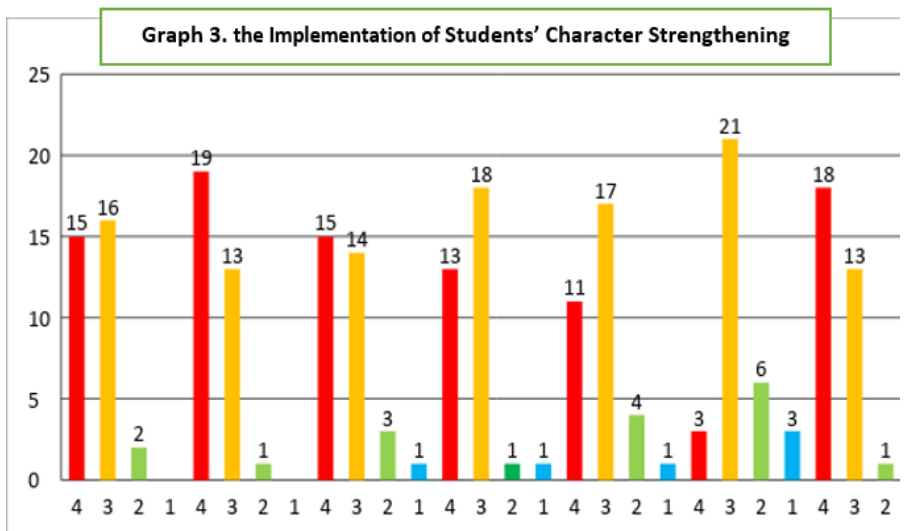

The data in the graph above shows that the implementation of student character strengthening programs in the border area generally shows opinions that vary from the teachers to the 7 dimensions studied. In principle, the implementation of the character education strengthening program can be carried out quite well. The following are specified dimensions based on the graphical presentation above.

a. The implementation of character education programs is carried out fairly balanced when viewed from the dimensions of implementation. This is based on the opinions of teachers that most $(48.48 \%)$ said the implementation of character education programs has been carried out through the learning process and outside the learning process.

b. The participation of all teachers in the field of study in the implementation of character education can be carried out quite well, although judging from the participation of all teachers the field of study has not been optimal. This is based on data showing that $57.57 \%$ of teachers said that strengthening the character of students through the learning process was carried out in all fields of study / through all subjects.

c. Strengthening the character through various activities outside the learning process (extracurricular activities) can be implemented programmatically, and thus the implementation is good enough. This is supported by questionnaire data as presented through the previous graph which shows that as many as $45.45 \%$ of teachers said that they had been programmed properly. Some teachers $(42.42 \%)$ said the teacher was good enough.

d. Strengthening character education for students is carried out continuously or continuously. This statement is supported by data from questionnaire data as presented through the previous graph which shows as many as $54.54 \%$ of teachers said that coaching / strengthening student character is carried out continuously without having to wait for students to experience problems.

e. The involvement of people in the formation of student character, especially for students with problems can be done quite well. This statement is supported by data from questionnaire data as presented through the previous graph which shows that most of the teachers $(51.51 \%)$ of the teachers said that coaching / strengthening students' character was carried out by taking care of parents when students experienced problems.

f. Government involvement in strengthening student character has been done optimally. This is supported by data from the teacher's answers, most of which $(63.63 \%)$ said that so far the sub-district, regency or government agencies have been quite involved, and as many as $18.18 \%$ said that they were less involved.

g. The implementation of control or supervision conducted by the school in the implementation of the student character strengthening program has been done very well. This is supported by the teacher's answer data, as many as $54.54 \%$ said it was very good, and as many as $39.39 \%$ said it was good. 
4. Evaluation and Follow-up Program for Strengthening Character of Students in Schools in Border Regions The results of data analysis related to the evaluation and follow-up of the program to strengthen the character of students in schools in the border areas are as illustrated in the following graph.

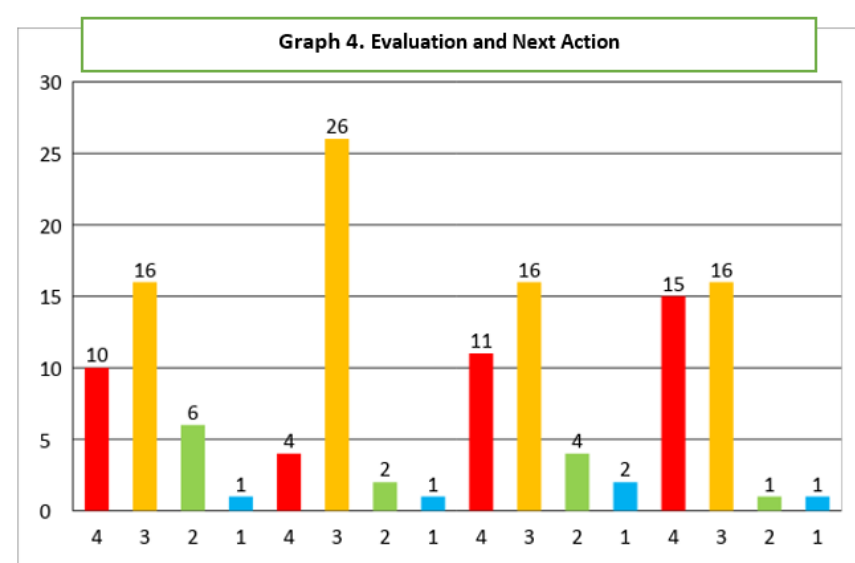

Data on the above chart shows that the evaluation and follow-up of programs to strengthen the character of students in the border area that includes the dimensions of the implementation, the discussion of the results of the evaluation, remediation efforts as well as coaching and sanctions against violations of the rules can be explained as follows:

a. In connection with the evaluation of the strengthening of character education by most of the teachers $(48.48 \%)$ said that they agreed that this was implemented in a planned and programmed manner. However, this implementation has not been optimal, because based on the data, only some teachers $(30.30 \%)$ said that they strongly agreed that this was done.

b. With regard to the discussion of the results of the evaluation of the student character strengthening program, most teachers $(78.78 \%)$ said they agreed this was done. Of the number of teachers, only a small number $(12.12 \%)$ of teachers said that the results of the evaluation of student coaching / character were specifically discussed in school meetings.

c. Efforts to improve student character strengthening programs that are based on the results of evaluations are still not optimal. This is based on data / information from the teacher's answers, most of which (48.48) said that they agreed that efforts to improve student character strengthening programs were based on the results of analysis and evaluation. While only $33 \%$ of teachers said that they strongly agreed that the improvement of the student character strengthening program was based on the results of analysis and evaluation as expected. d. Emphasis on coaching compared to sanctions imposed by schools in strengthening the character of students in general has been done well. This is based on the information conveyed, where most teachers $(48.48 \%)$ said they agreed this was done. And even seen from almost the same number $(45.45 \%)$ the teachers who said strongly agreed that this was done.

Based on interviews with a number of teachers, a number of specific things were revealed about strengthening the character of students in the border areas;

1) Strengthening students' character in particular is especially religious character, strengthening the sense of nationalism in students that is carried out routinely every Friday. Strengthening the character of patriotism (nationalism) for students is done by gathering students every morning before entering the class to sing the Indonesia Raya song, and each will start and end the lesson by singing compulsory songs together.

2) The forms of teacher involvement in strengthening the character of students in addition to through the learning process in class, are also carried out, among others through flag ceremonies, lines of marching, coaching and supervision of student order in dressing, as well as providing motivation for students. In addition there are scout activities, training in speeches, theater training and similar activities. While the involvement of other parties in the formation of the character of students, among others, in the form of socialization of the police about traffic rules. From the National Narcotics Agency (BNN) about drugs. Whereas from the Health Office gave counseling about health, and carried out treatment to students.

3) Supporting factors are the strengthening of character education in schools, particularly the synergy of all parties, including schools, communities and parents. There has been good communication between schools and parents, causing problems that occur at school, especially those with direct links to students can be resolved quickly. While the inhibiting factor is the influence of mass media which tends to be used by students who are not infrequently used for things that are not good. Another obstacle is the students' lack of motivation, the limited number of teaching staff and education personnel in the border area. In addition, the unavailability of specific programs that reflect or are in accordance with the needs and conditions of the border area are also part of the discussion in strengthening optimistic character education.

\section{Discussion}

The existence of a student character strengthening program that has been compiled by schools and known by all teachers is a very important part, because the availability of programs is a fundamental milestone so that activities can be 
implemented and developed. On the other hand, character strengthening programs that are known by teachers provide enormous benefits and impacts, both from the dimensions of the teachers themselves and from the school dimension. For teachers, knowing this program will enable it to further strengthen its understanding of character strengthening programs that will be implemented. In turn this can foster the participation and responsibility of teachers in the implementation of character strengthening. A number of experts reveal this involvement is important because the initial step of planning in the management of character education is to instill a shared awareness and equate the perception of the importance of an activity that is in all activities in schools or educational institutions, so that these values can become habits by all elements that in the institution. In several discussions it was revealed that after obtaining the same perception about the importance of strengthening the value / character education program, the school needed to translate the school's vision and mission in the character education framework. Furthermore, the principal along with teachers and education personnel as well as the community or parents / guardians of students (committees) or even counselors must take planning steps: (1) determine the character values that will be applied in the school concerned, (2) design integrated character programs with all subjects in the madrasah, (3) designing conducive school conditions for the implementation of character education, (4) designing classrooms that are conducive to the implementation of character education, (5) designing environment outside madrasah that is conducive to the implementation of character education (Salim, 2015).

An important step taken in planning is to socialize the importance of character education in schools based on the education output so far which is not appreciative of value / character education. This step also needs to be affirmed by the basis or regulation of the need for schools or madrasas to apply character education in an integrated and comprehensive manner so that the expected changes in performance of the school, especially in developing students' attitudes and intellectuals can be achieved well. Roso (2013), through his research revealed comprehensive character education in the school he studied by basing on religion in the developed curriculum. The results of his study also show that by implementing religion-based character education, cultural values and school culture have colored integrated character education programs. This is important so that the legal basis for the implementation of character education can be explained by the principal, so that all stakeholders are able to carry out consciously and are responsible for the implementation of character strengthening that will be carried out.

School creativity to develop and develop their own character strengthening programs that are not only dependent on government programs or the Education Office is a step that needs to be appreciated. School initiatives to choose and determine activities that are appropriate and appropriate to the conditions of students and schools are important factors for the realization of an effective character education program.
This school initiative is also an indicator of the growing awareness of teachers and the school community in placing the importance of strengthening character education. Even in theory, as well as the reality, teacher independence is a key factor in supporting the implementation of character education. The research conducted by Prasetyo and Marzuki (2016: 227) revealed that the results of his research on the AlAzhar Islamic School before the teacher kept the character on students, the teachers first gave examples, examples or examples especially with regard to the dimensions of the character of students to be developed.

Community involvement is a very important factor in realizing the success of strengthening the character of students in school. Society and parents are not only teachers and school partners, but more than that, the existence of parents and society can be a spirit and motivator for schools to be more enthusiastic in developing school programs. In reality, there are still quite a lot of parents and communities who have not shown great concern for the importance of this role. Research conducted by Wuryandani, et al. (2016: 208) revealed among the constraints of the implementation of independence character education, among others (1) lack of consistency of parents in following school rules to develop the character of students, (2) on the other hand schools have not been able to integrate character education of comprehensive independence in the learning process in the classroom. Therefore, things that can hinder the implementation of this character strengthening must be a serious concern and can be anticipated in order to realize the program as a whole. The responsibility of education is a shared responsibility between school, family and society. The three components must work together so that character education efforts can be effective and efficient (Wido, 2010). This synergy also must continue to be built and should be a rational choice to be able to integrate character education into the context of the lives of students.

\section{CONCLUSIONS}

\section{A. Conclusions}

Based on the description of the results of the research and discussion, the researcher can draw conclusions as follows:

1) In principle, schools in border areas already have student character strengthening programs. Similarly, schools have good initiatives in developing student character strengthening programs.

2) The specificities of the program or priority program for strengthening national character for students designed by schools in border areas are generally not too visible, although there are certain emphases at the time of implementation. This causes the characteristics of the character strengthening program in the border area to be seen. In the meantime, almost all teachers have the perception that schools in border areas are very important to have special programs in strengthening students' character. 
3) Actualization of the implementation of the national character strengthening program for students in border areas in general has been done quite well. Involvement of parents, sub-district governments, regencies or government agencies and in discussions about student character strengthening programs still need to be optimized. In the dimension of control or supervision, schools have done well in the implementation of student character strengthening programs.

4) Supervision, monitoring, evaluation and follow-up of character strengthening programs for students in the border area have been carried out. Discussion of the results of the evaluation to determine specific improvement steps in the form of joint discussions still needs to be optimized.

5) The main supporting factors for the implementation of character strengthening are the existence of good synergy between schools, parents and the community. While the obstacles that are still faced are student learning motivation that needs to be continued, lack of educators and education as well as learning facilities and program socialization and parental involvement that have not been implemented in a comprehensive and optimal manner.

\section{REFERENCES}

Ahmad, Salim. 2015. Manajemen Pendidikan Karakter di Madrasah (Sebuah Konsep dan Penerapannya). Jurnal TARBAWI, Volume 1 Nomor 2, Juli - Desember 2015. ISSN: 2442-8809

Amin, Maswardi M. 2013. Pendidikan Karakter Anak Bangsa. Edisi Revisi. Jakarta: Baduose Media Jakrta)

Aunurrahman. 2010. Pendidikan Multikultural Menuju Harmoni Sosial dan Pencegahan Konflik. Pendidikan Karakter, Jurnal Publikasi Ilmiah Pendidikan Umum dan Nilai, Vol. 2 No. 2 Juli 2010-ISSN 20860226. Asosiasi Sarjana dan Dosen Pendidikan Umum dan Nilai Indoensia.
Azis, Samsuddin. 2009. Karakter Pemuda Pilihan. Jakarta: RMBOOKS)

Majid, Abdul. 2010. Peranan Pendidik dalam Upaya Membentuk Karakter Peserta Didik. Pendidikan Karakter, Jurnal Publikasi Ilmiah Vol. 2 No. 2 Juli 2010. ISSN 20860226

Maunah, Binti. 2015. Implementasi Pendidikan Karakter dalam Pembentukan Kepribadian Holistik Siswa. Jurnal Pendidikan Karakter Tahun V, Nomor 1, April 2015. ISSN: 2089-5003.

Partnership Policy Paper No. 2/2011. Kebijakan Pengelolaan Kawasan Perbatasan Indonesia. The Partnership for Governance Reform

Prasetyo, Danang dan Marzuki. 2016. Pembinaan Karakter Melalui Keteladaan Guru Pendidikan Kewarganegaraan di Sekolah Islam Al Azhar Yogyakarta. Jurnal Pendidikan Karakter Tahun VI, Nomor 2, April 2016. ISSN: 2089-5003.

Revell, Lynn\& James Arthur. 2007. Character education in schools and the education of teachers. Journal of Moral Education, vol 36, 2007 Published online: 13 Mar 2007. https://doi.org/10.1080/ 03057240701194738.

Roso, Calvin G. 2013. Study of Life and Experience. Journal of Research on Christian Education. Volume 22, 2013 - Issue : Education in the Abrahamic Faith Traditions. Published online: 15 Apr 2013.

Soedarsono, Soemarno. 2009. Karakter Mengantar Bangsa dari Gelap Menuju Terang. Jakarta: PT. Elex Media Komputindo.

Undang-Undang Republik Indonesia Nomor 25 Tahun 2000 Tentang Program Pembangunan Nasional (PROPENAS) TAHUN 2000-2004.

Wido, Mardi. 2010. Membangun Pendidikan Karakter Bangsa Berbasis Budaya Sekolah dan Komunitas Sekolah. Prosiding Seminar, Aktualisasi Pendidikan Karakter Bangsa, 15 November 2010. Bandung: Widya Iswara Press.

Wuryandani Wuri, Faturrohman, Unik Ambarwati. 2016. Implementasi Pendidikan Karakter Kemandirian di Muhammadiyah Boarding School. Cakrawala Pendidikan, Jurnal Ilmiah Pendidikan, Juni 2016, Th. XXXV, No. 2. Yogyakarta: LPPMP Universitas negeri Yogyakarta. 